\title{
Hereditary Breast and Ovarian Cancer: Structures of Care in Austria
}

Regina Kroiss Diana Bikas Verena Winkler Daniela Muhr Christine Fürhauser Maria Tea Elisabeth Fleischmann Austrian Hereditary Breast and Ovarian Cancer Group Ernst Kubista Teresa Wagner

\section{Key Words}

Breast cancer - Ovarian cancer - Genetic testing - BRCA1 . BRCA2

\section{Summary}

Mutations in the BRCA1 or BRCA2 genes result in a significantly increased risk of breast and ovarian cancer. Austrian women who carry a BRCA1 mutation have a risk of $85 \%$ for breast cancer and $53 \%$ for ovarian cancer up to 70 years of age. At-risk women have 2 medical options: closely monitored early detection using mammography, breast ultrasound, and MRI, as well as tumor markers and vaginal ultrasound, or real risk reduction through prophylactic removal of the breast tissue and/or the ovaries. As awareness of such a high risk of disease may cause a great deal of distress, and because prophylactic surgeries offer only very drastic measures for risk reduction, a special multidisciplinary care concept is of particular importance. This care starts with comprehensive genetic counseling before performing molecular genetic analysis and must be continued after a genetic predisposition for breast and ovarian cancer has been identified. Right from the start, special schooling in Austria has ensured that patients in all cooperating genetic counseling centers are counseled, selected, and followed-up according to the same criteria.

\author{
Schlüsselwörter \\ Mammakarzinom · Ovarialkarzinom - Genetische Unter- \\ suchung · BRCA1 - BRCA2
}

\section{Zusammenfassung}

Mutationen in den Genen BRCA1 oder BRCA2 führen zu einer massiven Erhöhung des Brust- und Eierstockkrebsrisikos. Österreichische Trägerinnen einer BRCA1-Mutation haben ein Lebenszeitrisiko von 85\% für Mammakarzinome und 53\% für Ovarialkarzinome. Betroffenen Frauen stehen zwei medizinische Optionen zur Verfügung: engmaschige Früherkennung mit Mammografie, Brustultraschall und MRI sowie Tumormarkern und Vaginalultraschall oder echte Risikoreduktion durch prophylaktische Entfernung des Brustgewebes bzw. der Eierstöcke. Da das Wissen um ein so hohes Erkrankungsrisiko eine große Belastung darstellen kann und mit prophylaktischen Operationen nur sehr drastische Maßnahmen der Risikoreduktion zur Verfügung stehen, ist ein spezielles multidisziplinäres Betreuungskonzept besonders wichtig. Diese Betreuung beginnt bei einer ausführlichen Beratung vor der genetischen Untersuchung und muss nach der Identifikation einer genetischen Prädisposition für Brust- und Eierstockkrebs fortgesetzt werden. Durch Schulungen wurde in Österreich von Beginn an sichergestellt, dass Patientinnen in allen kooperierenden Beratungsstellen nach den gleichen Kriterien beraten, selektiert, aufgeklärt und nachbetreut werden.

\begin{tabular}{ll}
\hline KARGER & @ 2006 S. Karger GmbH, Freiburg \\
Fax +497614520714 & Accessible online at: \\
$\begin{array}{l}\text { E-mail Information@Karger.de } \\
\text { www.karger.com }\end{array}$ & www.karger.com/brc \\
&
\end{tabular}

Univ.-Prof. Dr. Teresa Wagne

Universitätsklinik für Frauenheilkunde

Klinische Abteilung für Spezielle Gynäkologie

Währinger Gürtel 18-20, 1090 Wien, Österreich

Tel. +431 40400-2801 / -2881, Fax +43 14066749

E-mail Teresa.Wagner@meduniwien.ac.at 


\section{Hereditary Breast and Ovarian Cancer}

Breast cancer is the most common form of carcinoma in women in most industrialized countries. The risk of a woman to develop breast cancer during her lifetime is $10-12 \%$. For $5-10 \%$ of all affected women - which in Austria amounts to 200-450 women annually - inherited changes in the genotype are the cause of the disease. This type of breast cancer often affects several family members and occurs at early ages. With a lifetime incidence of $1-2 \%$, ovarian cancer is less common than breast cancer; however, diagnosing ovarian cancer in the early stages is much less reliable, which is why this disease is the number one killer of all the gynecological forms of cancer.

In the mid-1990s, two genes were sequenced that account for a considerable part of the hereditary breast and ovarian cancer syndromes: BRCA1 [1] and BRCA2 [2]. International studies on female BRCA1 mutation carriers from high-risk families yielded a risk of disease of over $80 \%$ for breast cancer and $40-60 \%$ for ovarian cancer up to 70 years of age [3]. In terms of breast cancer, the results for BRCA 2 mutation carriers are comparable [4], yet, on average, the disease occurs somewhat later than in BRCA1 mutation carriers. The risk of ovarian cancer for BRCA2 mutation carriers is estimated to be $27 \%$ by age of 70 years [4].

Since the hereditary risk of disease can be modified by various gynecological, genetic, and environmental factors, we conducted a study [5] with 264 Austrian women from 160 different families who were identified as being carriers of a BRCA1 mutation in our laboratory. The results (table 1) show an $85 \%$ risk of disease for breast cancer up to 70 years of age. Every second woman develops the disease even before her 45th birthday. Additionally, the risk of ovarian cancer is $53 \%$. In accordance with two other studies [6, 7], our calculations also show that female carriers of a BRCA1 mutation who were born in the last several decades (1958 or later) have an even higher risk of disease than carriers of earlier generations.

Due to the lower frequency of BRCA2 mutations, the number of identified mutation carriers is not yet large enough to calculate BRCA2 risk estimates specifically for the Austrian population.

\section{Genetic Counseling for Families with Hereditary Breast and Ovarian Cancer}

In 1994, immediately after the BRCA1 gene had been sequenced, the first Austrian counseling center for hereditary breast and ovarian cancer was founded at the Department of Senology at the Vienna General Hospital. Ever since, families with a cumulative incidence of breast and/or ovarian cancer can undergo genetic counseling and, if indicated, molecular genetic testing.
During the first genetic counseling session, the patient's motivation and state of knowledge are determined. A central component of the counseling process is the compilation of a complete family history (pedigree analysis). For a woman or man to undergo a molecular genetic examination for mutations in the BRCA1 and BRCA2 gene in Austria, one of the following eligibility criteria must be met in the family history: on one side of the family at least (a) 2 cases of breast cancer before the age of 50, (b) 3 cases of breast cancer before the age of 60 , (c) 1 case of breast cancer before the age of 50 and 1 case of ovarian cancer, (d) 2 cases of ovarian cancer, (e) 1 case of breast cancer before the age of 35 , or (f) male and female breast cancer.

Eligible women and men are informed in detail about the medical significance of mutations in BRCA1/2, about heredity, early detection, and prophylactic surgery, and about the subsequent procedure of genetic testing. Additionally, they are informed that all patients are offered both a comprehensive medical care program as well as psychosocial care. At the end of the pre-test counseling session, the counselees must decide whether they wish to undergo BRCA1 and BRCA2 analysis. After signing a special informed consent form, a blood sample is taken in order to obtain DNA material for examination. All counseled patients receive a short written summary of the pre-test counseling session.

Once the results of the molecular genetic examination are available, the counselees receive a written invitation to schedule an appointment to discuss their genetic test results. After the counselees have signed the informed consent form, they are given their results. Then, the detailed written medical findings are discussed with the patients. These findings include information about risk of disease and heredity, recommendations regarding early detection, and, for female mutation carriers, information about the possibility of prophylactic surgery. Options regarding further medical and psychosocial care are also discussed.

\section{Genetic Counseling Centers in Austria}

In order to ensure nation-wide care of families with hereditary breast and ovarian cancer in Austria, 9 two-day educational sessions for physicians have been conducted since 1996 with participants from all parts of Austria. As a result, 34 additional genetic counseling centers were established in Austria, where families are counseled according to the same guidelines and eligibility criteria. Molecular genetic analysis is carried out centrally, at a special laboratory of the Department of Senology in Vienna. The patients, however, are counseled in the individual genetic counseling centers and also cared for and followed-up on site. A list of all genetic counseling centers can be found at www.brustgesundheit.at/brustgenberatung. 
Table 1. Cancer risks associated with BRCA1 mutations at ages $30-70$ years

\begin{tabular}{llllll}
\hline \multicolumn{7}{c}{ Cumulative risk $(95 \%$ confidence interval) } & & \\
\cline { 2 - 6 } Age, years & 30 & 40 & 50 & 60 & 70 \\
\hline Breast cancer & $0.08(0.05-0.12)$ & $0.36(0.29-0.42)$ & $0.61(0.54-0.69)$ & $0.74(0.66-0.83)$ & $0.85(0.75-0.96)$ \\
Ovarian cancer & $0.004(0-0.012)$ & $0.03(0.004-0.05)$ & $0.25(0.16-0.33)$ & $0.40(0.29-0.52)$ & $0.53(0.37-0.68)$ \\
\hline
\end{tabular}

Table 2. BRCA1 mutation rate in families with breast cancer only (HBC), breast and ovarian cancer (HBOC), ovarian cancer only (HOC), and male and female breast cancer

\begin{tabular}{|c|c|c|}
\hline & $\begin{array}{l}\text { Studied } \\
\text { families, n }\end{array}$ & $\begin{array}{l}\text { Families with BRCA1 } \\
\text { mutation, } \mathrm{n}(\%)\end{array}$ \\
\hline \multicolumn{3}{|l|}{ Family history } \\
\hline $1 \mathrm{BC}<35$ years & 96 & $12(13)$ \\
\hline $2 \mathrm{BC}<50$ years & 193 & $20(10)$ \\
\hline $3 \mathrm{BC}<60$ years & 110 & $21(19)$ \\
\hline$\geq 4 \mathrm{BC}$ any age & 61 & $3(5)$ \\
\hline$\geq 4 \mathrm{BC}<60$ years & 53 & $18(34)$ \\
\hline $1 \mathrm{BC}<50+1 \mathrm{BC}>50$ years & 65 & $3(5)$ \\
\hline $2 \mathrm{BC}<60$ years & 11 & $1(9)$ \\
\hline $3 \mathrm{BC}$ any age & 70 & $7(10)$ \\
\hline HBC families total & 659 & $85(13)$ \\
\hline $\mathrm{BC} / \mathrm{OC}$ in a woman & 61 & $32(52)$ \\
\hline $1 \mathrm{BC}+1 \mathrm{OC}$ & 59 & $13(22)$ \\
\hline $1 \mathrm{BC}+\geq 2 \mathrm{OC}$ & 22 & $6(27)$ \\
\hline $2 \mathrm{BC}+\geq 1 \mathrm{OC}$ & 54 & $8(15)$ \\
\hline$\geq 3 \mathrm{BC}+1 \mathrm{OC}$ & 43 & $14(33)$ \\
\hline$\geq 3 \mathrm{BC}+\geq 2 \mathrm{OC}$ & 9 & $5(56)$ \\
\hline HBOC families total & 248 & $78(31)$ \\
\hline HOC families & 52 & $15(29)$ \\
\hline Male and female BC & 33 & $1(3)$ \\
\hline Total & 992 & $179(18)$ \\
\hline
\end{tabular}

$\mathrm{BC}=$ Breast cancer, $\mathrm{OC}=$ ovarian cancer.

\section{Molecular Genetic Analyses}

Mutations in BRCA1 and BRCA2 may occur at any location of the gene. An exact molecular genetic analysis must therefore include all coding gene segments, even if the genes are very large (BRCA1: around 13,000 base pairs, BRCA2: around 16,000 base pairs). Originally, direct sequencing was regarded as the gold standard of molecular genetic testing. In this technique, the gene sequence is analyzed base pair by base pair. The method is reliable, but it is also very expensive, relatively slow and requires substantial human resources.

An alternative, which has been available for years, is denaturing high-performance liquid chromatography (DHPLC). This method no longer laboriously 'spells' the DNA, but rather depicts the base pair changes (mutations). Only aberrant DHPLC chromatograms are then further examined using direct sequence analysis in order to determine the exact type and localization of the mutation. In an international comparative study [8], we were able to prove that this method is as re- liable as the sequencing method, but faster, less labor-intensive, and significantly less expensive.

As the rate of BRCA1 mutations in Austrian high-risk families is about twice that of the rate of BRCA2 mutations, molecular genetic analysis is performed in two steps: First, BRCA1 is fully analyzed, and the patients are informed about the results. Only if no BRCA1 mutation is found, a subsequent analysis of BRCA2 is undertaken. This procedure is far more efficient than carrying out both analyses in parallel. If a mutation has already been identified in one family member, then all other family members can undergo a targeted examination to quickly test for the presence of this mutation.

In the Netherlands, Sweden, Germany, and Finland, social insurance pays for molecular genetic analyses of BRCA1 and BRCA2. In Austria, molecular genetic studies of BRCA1 and BRCA2 are financed through third-party funds, research funding, and donations.

\section{Families with BRCA1/BRCA2 Mutations in Austria}

From 1994 until the end of 2004, 1,189 families from all over Austria with a total of 1,944 family members met at least one of the above-indicated eligibility criteria and opted to undergo molecular genetic testing. Through the end of March 2005, analysis of BRCA1 was completed in 992 families. A diseaseassociated mutation was identified in 179 families (18.0\%); in families with at least one woman affected by breast or ovarian cancer tested, it was $23.1 \%$. The mutation rate clearly depends on the family history (table 2).

By the end of March 2005, analysis of BRCA2 was completed in 602 families. A BRCA2 mutation was identified in 53 families $(8.8 \%$ total; $11.0 \%$ in families with at least one tested member affected by breast or ovarian cancer).

\section{BRCA1 and BRCA2 Mutation Carriers}

Thus, by the end of March 2005, a disease-related BRCA1 or BRCA2 mutation was identified in 232 Austrian families. In these families, 393 individuals ( 355 women and 38 men) were identified as mutation carriers. Molecular genetic analyses also proved that another 181 persons from mutation families (158 women and 23 men) had not inherited the mutation segregating in the family, and their risk for breast or ovarian cancer as well as the risk of disease for their descendants was therefore not increased.

$61 \%$ percent of female mutation carriers had already devel- 
Table 3. Early detection for female carriers of a BRCA1/2 mutation

\begin{tabular}{llllll}
\hline Examination & $\begin{array}{l}\text { Start at age, } \\
\text { years }\end{array}$ & $\begin{array}{l}\text { First } \\
\text { examination }\end{array}$ & $\begin{array}{l}\text { After 6 } \\
\text { months }\end{array}$ & $\begin{array}{l}\text { After 12 } \\
\text { months }\end{array}$ & $\begin{array}{l}\text { After } 18 \\
\text { months }\end{array}$ \\
\hline Palpation & 18 & $\times$ & $\times$ & $\times$ & $\times$ \\
Breast ultrasound & 18 & $\times$ & $\times$ & $\times$ & $\times$ \\
Mammography & 25 & $\times$ & - & $\times$ & - \\
MRI & 25 & $\times$ & $\times$ & $\times$ & $\times$ \\
Vaginal ultrasound & 35 & $\times$ & $\times$ & $\times$ & $\times$ \\
Tumor markers for ovarian & 35 & $\times$ & $\times$ & $\times$ & $\times$ \\
$\quad$ cancer & & & & & \\
\hline
\end{tabular}

The recommendation for magnetic resonance imaging (MRI) of the breasts is twice per year for women under 40 years of age, and yearly for women over 40 .

oped cancer. Of these, $78 \%$ of the women developed breast cancer, $23 \%$ of whom are suffering from bilateral disease. $12 \%$ of the female mutation carriers have developed ovarian cancer, and $10 \%$ suffer from breast and ovarian cancer. The occurrence of cervical cancer and endometrial cancer is very rare. Male mutation carriers rarely develop prostate cancer or male breast cancer. $39 \%$ of the women currently show no signs of disease. The average age of the healthy female mutation carriers is 38.6 years.

\section{Medical Care for Female Mutation Carriers}

All patients in whom a mutation was identified, and who therefore have a very high risk of developing breast and ovarian cancer, are offered gynecological-oncological examinations at 6-month intervals (table 3 ). The majority of the female mutation carriers decides to undergo these examinations for the purpose of early cancer detection. According to the current state of knowledge, the combined sensitivity regarding early detection of breast cancer for mammography, magnetic resonance imaging (MRI) of the breasts, and breast ultrasound is at least $95 \%$ [9]. The value of vaginal ultrasound and the determination of tumor markers (CA 125) for the early detection of ovarian cancer has not been reliably proven. However, these measures are offered for want of other early detection options.

In Vienna, early detection examinations are offered in cooperation with the Department of Radiodiagnostics. In order to maximize compliance, all women who participate in the early detection program are actively contacted via telephone and reminded of their upcoming examinations. The genetic counseling center schedules the examinations, which are usually coordinated such that all can take place on the same day. The women are very positive about this offer and have readily accepted this possibility. Therefore, all female Austrian mutation carriers are now given the option of a central telephonic 'reminder service'. In addition, a national radiology work group has been established that specializes in early detection of hereditary breast and ovarian cancer. The participating radiology centers offer the recommended examinations to mutation carriers.

\section{Risk-Reducing Surgery}

\section{Prophylactic Mastectomy}

Based on the current state of knowledge, prophylactic mastectomy greatly decreases the risk of developing breast cancer. In a retrospective study [10] with a mean follow-up period of 13.4 years, a risk reduction of $90-100 \%$ was identified for female mutation carriers who had undergone prophylactic mastectomy. Two prospective studies [11, 12] also showed the same degree of risk reduction through prophylactic mastectomy.

In the Austrian population, $16 \%$ of the identified female mutation carriers so far have decided to minimize their risk of disease through preventive removal of the breast tissue. In international studies, this number ranged between 0 and $51 \%$ $[13,14]$.

\section{Prophylactic Ovariectomy}

Currently, two large studies on the effectiveness of prophylactic removal of the adnexa are available: a prospective study involving 170 women with a mean follow-up of 2 years [15], and a retrospective study with 551 women and an 8-year follow-up period [16]. Both studies compared women who had opted for or against prophylactic removal of the adnexa after molecular genetic analysis in view of their status as mutation carriers. Both studies show that prophylactic adnexal removal decreases the risk of developing ovarian cancer by more than $95 \%$. Moreover, prophylactic adnexal removal decreases the risk of developing breast cancer by about $50 \%$. This effect occurred despite the frequent use (around 50\%) of hormone replacement therapy in this collective.

Given the very limited possibilities of detecting ovarian cancer in its early stages, a prophylactic ovariectomy surely represents an option that needs to be considered carefully together with the women at risk. In the Austrian population, $42 \%$ of the identified female mutation carriers so far have decided to undergo prophylactic ovariectomy, but a clear increase of the acceptance of this preventive procedure has been observed in recent years. 


\section{Psychosocial Care}

Being aware of their genetic predisposition for breast and ovarian cancer presents a great deal of distress for many families. The counseling and care concept should therefore be structured in a multidisciplinary manner and should also include psychosocial components. In order to ensure psychosocial patient care after genetic test result disclosure across Austria, a pilot project has been conducted since June 2001. Based on a need analysis, a low-threshold care concept was developed specifically for families with hereditary breast and ovarian cancer. In addition to multidisciplinary pre-test counseling and result disclosure, all members of families that carry a mutation are actively offered a follow-up appointment after result disclosure. Additionally, members of mutation families always have the option of receiving psychological counseling if necessary, particularly if they consider prophylactic surgery. As part of the care concept, quarterly psycho-educational seminars are offered to all members of mutation families in order to support their psychological well-being. Preliminary results show that all components of the care concept are accepted very well by the patients.

\section{Acknowledgements}

The 'Pilot Project for Psychosocial Care of Families with Hereditary Breast and Ovarian Cancer' was supported by the Fonds Gesundes Österreich, the Jubiläumsfonds der Österreichischen Nationalbank, the Österreichische Krebshilfe, the Private Trust for Breast Health and the Austrian Society of Endocrinological Oncology.

Members of the Austrian Hereditary Breast and Ovarian Cancer Group are:

E. Klug, Oberwart; W. Döller, Wolfsberg; T. Eberl, St. Veit/Glan; E. P. Forsthuber, S. Sussitz, Klagenfurt; G. Hudelist, K. Unterrieder, Villach; E. Melbinger, Wolfsberg; E. Ropp, Klagenfurt; M. Bachner, St. Pölten; T. Payrits, Wiener Neustadt; A. Meixner, Horn; C. Baldinger, M. Baldinger, Wels; H.-C. Duba, Linz; R. Kusatz, Wels; R. Leikermoser, D. Krichbaumer, W. Hochmeir, Linz; C. Schmidhammer, S. Pöstlberger, R. Helfgott, Linz; I. Stadlhuber, Wels; C. Tausch, G. Wahl, Linz; C. Menzel, S. Glück; B. Mlineritsch, P. Mayer, Salzburg; W. Zeilmann, S. Schäfer, S. Berning, Schwarzach i. P.; M. Bauer, P. Konstantiniuk, Graz; T. Niernberger, W. Herz, H. Rabl, Leoben; E. Petru, Graz; P. Pittler, Leoben; A. Bachmann, K. Matthä, Hall in Tirol; C. Smekal-Schindelwig, Innsbruck; J. Wiegele, Kufstein; G. Windbichler, Innsbruck; H. Concin, M. Rohde, Bregenz; A. Haid, R. Köberle-Wührer, Feldkirch; A. Lang, A. Taraben, Feldkirch; T. Wagner, E. Kubista, R. Kroiss, D. Bikas, M. Tea, Vienna.

\section{References}

1 Miki Y, Swensen J, Shattuck-Eidens D, Futreal PA, Harshman K, Tavtigian S, Liu Q, Cochran C, Bennett LM, Ding W, Bell R, Rosenthal J, Hussey C, Tran T, McClure M, Frye C, Hattier T, Phelps R, Haugen-Strano A, Katcher H, Yakumo K, Gholami Z, Shaffer D, Stone S, Bayer S, Wray C, Bogden R, Dayananth P, Ward J, Tonin P, Narod S, Bristow PK, Norris FH, Helvering L, Morrison P, Rosteck P, Lai M, Barrett JC, Lewis C, Neuhausen S, CannonAlbright L, Goldgar D, Wiseman R, Kamb A, Skolnick MH: A strong candidate for the breast and ovarian cancer susceptibility gene BRCA1. Science 1994:266:66-71.

2 Wooster R, Bignell G, Lancaster J, Swift S, Seal S, Mangion J, Collins N, Gregory S, Gumbs C, Micklem G, Barfoot R, Hamoudi R, Patel S, Rice C, Biggs P, Hashim Y, Smith A, Connor F, Arason A Gudmundsson J, Ficenec D, Kelsell D, Ford D, Tonin P, Bishop DT, Spurr NK, Ponder BAJ, Eeles R, Peto J, Devilee P, Cornelisse C, Lynch H, Narod S, Lenoir G, Egilsson V, Barkadottir RB, Easton DF, Bentley DR, Futreal PA, Ashworth A, Stratton MR: Identification of the breast cancer susceptibility gene BRCA2. Nature 1995;378:789792.

$\checkmark 3$ Easton DF, Ford D, Bishop DT: Breast and ovarian cancer incidence in BRCA1-mutation carriers Breast Cancer Linkage Consortium. Am J Hum Genet 1995;56:265-271.

4 Ford D, Easton DF, Stratton M, Narod S, Goldgar D, Devilee P, Bishop DT, Weber B, Lenoir G, Chang-Claude J, Sobol H, Teare MD, Struewing J, Arason A, Scherneck S, Peto J, Rebbeck TR, Tonin P, Neuhausen S, Barkardottir R, Eyfjord J, Lynch H, Ponder BA, Gayther SA, Zelada-Hedman M: Genetic heterogeneity and penetrance analysis of the BRCA1 and BRCA2 genes in breast cancer families. The Breast Cancer Linkage Consortium. Am J Hum Genet 1998;62:676-689.
5 Kroiss R, Winkler V, Bikas D, Fleischmann E, Mainau C, Frommlet F, Muhr D, Fuerhauser C, Te M, Bittner B, The Austrian Hereditary Breast and Ovarian Cancer Group, Kubista E, Oefner PJ, Bauer P, Wagner TMU: Younger birth cohort correlates with higher breast and ovarian cancer risk in European BRCA1 mutation carriers. Hum Mut 2005:26:583-589.

6 King MC, Marks JH, Mandell JB, the New York Breast Cancer Study Group: Breast and ovarian cancer risks due to inherited mutations in BRCA1 and BRCA2. Science 2003;302:643-646.

7 Narod SA, Goldgar D, Cannon-Albright L, Weber B, Moslehi R, Ives E, Lenoir G, Lynch H. Risk Modifiers in carriers of BRCA1 mutations. Int J Cancer 1995;64:394-398.

8 Eng C, Brody LC, Wagner TM, Devilee P, Vijg J, Szabo C, Tavtigian SV, Nathanson KL, Ostrander E, Frank TS, the Steering Committee of the Breast Cancer Information Core (BIC) Consortium: Interpreting epidemiological research: blinded comparison of methods used to estimate the prevalence of inherited mutations in BRCA1. J Med Genet 2001;38:824-833.

-9 Warner E, Plewes DB, Hill KA, Causer PA, Zubovits JT, Jong RA, Cutrara MR, DeBoer G, Yaffe MJ, Messner SJ, Meschino WS, Piron CA, Narod SA: Surveillance of BRCA1 and BRCA2 mutation carriers with magnetic resonance imaging, ultrasound, mammography, and clinical breast examination. JAMA 2004;292:1317-25.

10 Hartmann LC, Sellers TA, Schaid DJ, Frank TS, Soderberg CL, Sitta DL, Frost MH, Grant CS, Donohue JH, Woods JE, McDonnell SK, Vockley CW, Deffenbaugh A, Couch FJ, Jenkins RB: Efficacy of bilateral prophylactic mastectomy in BRCA1 and BRCA2 gene mutation carriers. J Natl Cancer Inst 2001;93:1633-1637.
11 Meijers-Heijboer H, van Geel B, van Putten WL, Henzen-Logmans SC, Seynaeve C, Menke-Pluymers MB, Bartels CC, Verhoog LC, van den Ouweland AM, Niermeijer MF, Brekelmans CT, Klijn JG: Breast cancer after prophylactic bilateral mastectomy in women with a BRCA1 or BRCA2 mutation. N Engl J Med 2001;345:159-164.

12 Rebbeck TR, Friebel T, Lynch HT, Neuhausen SL, van't Veer L, Garber JE, Evans GR, Narod SA, Isaacs C, Matloff E, Daly MB, Olopade OI, Weber BL: Bilateral prophylactic mastectomy reduces breast cancer risk in BRCA1 and BRCA 2 mutation carriers: the PROSE Study Group. J Clin Oncol 2004;22:1055-1062.

13 Meijers-Heijboer EJ, Verhoog LC, Brekelmans CT, Seynaeve C, Tilanus-Linthorst MM, Wagner A, Dukel L, Devilee P, van den Ouweland AM, van Geel AN, Klijn JG: Presymptomatic DNA testing and prophylactic surgery in families with a BRCA1 or BRCA2 mutation. Lancet 2000;355:2015-2020.

14 Botkin JR, Smith KR, Croyle RT, Baty BJ, Wylie JE, Dutson D, Chan A, Hamann HA, Lerman C, McDonald J, Venne V, Ward JH, Lyon E: Genetic testing for a BRCA1 mutation: prophylactic surgery and screening behavior in women 2 years post testing. Am J Med Genet 2003;118A:201-209.

15 Kauff ND, Satagopan JM, Robson ME, Scheuer L, Hensley M, Hudis CA, Ellis NA, Boyd J, Borgen PI, Barakat RR, Norton L, Castiel M, Nafa K, Offit K: Risk-reducing salpingo-oophorectomy in women with a BRCA1 or BRCA2 mutation. N Engl J Med 2002;346:1609-1615.

16 Rebbeck TR, Lynch HT, Neuhausen SL, Narod SA, van't Veer L, Garber JE, Evans G, Isaacs C, Daly MB, Matloff E, Olopade OI, Weber BL, the Prevention and Observation of Surgical End Points Study Group: Prophylactic oophorectomy in carriers of BRCA1 or BRCA2 mutations. N Engl J Med 2002;346:1616-1622. 